\title{
Telomerase can't handle the stress
}

\author{
Susan Smith \\ Department of Pathology, Kimmel Center for Biology and Medicine of the Skirball Institute, New York University School of \\ Medicine, New York, New York 10016, USA
}

Telomerase counteracts the telomere shortening that occurs with each round of cell division. In normal human cells, telomerase is repressed, leading to telomere shortening that triggers replicative senescence. However, in most tumors, telomerase is up-regulated and is essential for telomere maintenance and tumor cell growth. Although long considered a viable target for tumor therapy, successful inhibition of telomerase in cancer therapy remains to be described. In this issue of Genes \& Development, Ahmed and Lingner (pp. 658-669) uncover a vulnerability in telomerase upon exposure of cancer cells to oxidative stress. It has long been known that telomeres are sensitive to damage by reactive oxygen species (ROS), but the impact of oxidation on telomerase function in living cells was not known. Using gene knockouts in colon cancer cells, the investigators demonstrate that the antioxidant enzyme peroxiredoxin 1 (PRDX1) and the nudix phosphohydrolase superfamily enzyme (MTH1) cooperate to retain, upon oxidative stress, telomeres in a telomeraseextendible state. Considering that cancer cells are more vulnerable to ROS than noncancer cells, this work may open new avenues targeting telomeres and telomerase in tumor cells.

Human telomeres are comprised of $5^{\prime}$-TTAGGG-3' repeats and the multisubunit shelterin complex. Shelterin proteins execute critical functions at telomeres, including protection from ligation by the nonhomologous end-joining machinery and recruitment of telomerase, a reverse transcriptase (hTERT) that uses an RNA template (hTR) for de novo repeat addition to the $3^{\prime}$ end. Telomerase counteracts the telomere shortening that results from the end replication problem and nucleolytic processing. Telomerase is active during embryogenesis but, with the exception of some stem cell compartments, repressed in the human soma, and, as a result, telomeres shorten. This shortening limits the replication potential of somatic cells, thereby serving a powerful tumor suppressor function. Most cancers overcome this barrier by activation of

[Keywords: MTH1; PRDX1; aging; cellular senescence; oxidative stress; telomerase; telomeres]

Corresponding author: susan.smith@med.nyu.edu

Article is online at http://www.genesdev.org/cgi/doi/10.1101/gad.316042. 118 . telomerase and ultimately rely on telomerase-mediated telomere lengthening for survival.

Reactive oxygen species (ROS) are generated by cellintrinsic factors and environmental exposures. Free nucleotide pools are highly susceptible to oxidation, and insertion of oxidized nucleotides into the genome during replication is both mutagenic and toxic. ROS-mediated damage of nucleotides and nucleic acids is countered by cellular antioxidant defenses that repair and prevent oxidative damage. In vitro studies show that telomeric DNA is more susceptible to cleavage by ROS than nontelomeric sequences (von Zglinicki 2002). The ROSinduced base modification, 8-oxo-7,8-dihydro-guanine (8-oxo G), is enriched in telomeric DNA (Oikawa and Kawanishi 1999). The base excision repair pathway can remove this base modification; however, this pathway requires a complementary DNA strand. Thus telomeres, which end in a single-stranded $3^{\prime}$ overhang of $\sim 50-100$ nucleotides, may experience persistent damage.

Recent studies indicate specific enzyme pathways that play a role in protection of telomeres from ROS. Peroxiredoxin 1 (PRDX1) belongs to a class of antioxidant enzymes that diminish the burden of ROS by reducing $\mathrm{H}_{2} \mathrm{O}_{2}$ to $\mathrm{H}_{2} \mathrm{O}$. The Lingner group (Aeby et al. 2016) showed previously that PRDX1 is enriched at telomeres and that its association is stimulated by ROS. Deletion of PRDX1 in HCT116 telomerase-positive cancer cells led to ROSstimulated cleavage of telomeres. Nudix hydrolase 1 (MTH1) converts 8-oxo-2'deoxyguanosine-5'-triphosphate (8-oxo dGTP) to 8-oxo dGMP, thereby preventing its incorporation during replication. The Opresko laboratory (Fouquerel et al. 2016) showed that depletion of MTH1 in telomerase-positive cancer cells with short telomeres led to telomere loss, fragility, and telomere DNA damage signaling.

The impact of ROS on telomere length maintenance by telomerase is not well understood. In vitro studies predicted that ROS could either promote or repress telomerase-mediated lengthening. In favor of repression, studies showed that the oligonucleotide substrate TTA-8oxoG-3'

(C) 2018 Smith This article is distributed exclusively by Cold Spring Harbor Laboratory Press for the first six months after the full-issue publication date (see http://genesdev.cshlp.org/site/misc/terms.xhtml). After six months, it is available under a Creative Commons License (Attribution-NonCommercial 4.0 International), as described at http:// creativecommons.org/licenses/by-nc/4.0/. 
could not be extended (Aeby et al. 2016). Moreover, it was shown that 8-oxo dGTP is used by telomerase as a substrate but, once incorporated, can function as a chain terminator (Aeby et al. 2016; Fouquerel et al. 2016). On the other hand, internal 8-oxo G suppresses G-quadruplex formation, thereby increasing telomerase accessibility and loading (Fouquerel et al. 2016; Lee et al. 2017). Finally, studies showed that ROS damage inhibits binding of the TTAGGG repeat-binding factors TRF1 and TRF2 in vitro (Opresko et al. 2005), which could be extrapolated to result in telomerase-mediated telomere elongation in vivo (van Steensel and de Lange 1997).

To determine the impact of ROS on telomerase and telomere length maintenance in living cells, Ahmed and Lingner (2018) investigated the consequences of disrupting PRDX1, MTH1, or both in HCT116 colon cancer cells. They showed that knockout of each gene led to increased expression of the other, suggesting that cells respond to disruption of one antioxidant system by increasing another. Consistent with this notion, increased oxygen induced expression of MTH1 and PRDX1. To measure their roles in suppressing guanine oxidation in the genome, they performed indirect immunofluorescence with antibodies against 8-oxo G. They observed an oxygen-dependent increase in 8-oxo G that was enhanced in the MTH1 knockout and further in the PRDX1/MTH1 double knockout. They next measured telomere length of cells propagated for multiple population doublings (PDs) under increasing oxygen concentrations $(5 \%, 20 \%$, and $40 \%)$. At $20 \% \mathrm{O}_{2}$, the PRDX1 knockout showed no shortening, the MTH1 knockout showed slight shortening, and the PRDX1/ MTH1 double knockout showed the most shortening. Only the MTH1 knockout could be passaged in $40 \% \mathrm{O}_{2}$, and it showed greater telomere shortening than at $20 \%$ $\mathrm{O}_{2}$. No significant shortening was detected in cells grown in $5 \% \mathrm{O}_{2}$. Together, these data indicate that PRDX1 and MTH1 are required to prevent oxygen-induced telomere shortening.

To analyze telomerase-mediated telomere lengthening, the investigators introduced a mutant allele of the POT1 shelterin subunit (POT1- $\triangle \mathrm{OB})$ shown previously to induce rapid telomere lengthening dependent on telomerase (Loayza and de Lange 2003). They showed that wild-type, MTH1 knockout, and PRDX1/MTH1 double-knockout cells elongated their telomeres at a similar rate when grown in $5 \% \mathrm{O}_{2}$. Wild-type cells maintained this rate at $20 \%$ and $40 \% \mathrm{O}_{2}$, whereas MTH1 knockout and PRDX1/ MTH1 double-knockout cells showed reduced rates of elongation at $20 \% \mathrm{O}_{2}$ and telomere shortening at $40 \%$ $\mathrm{O}_{2}$, thereby demonstrating a requirement for PRDX1 and MTH1 in telomerase-mediated telomere lengthening under oxidative stress. To evaluate the role of telomerase at chromosome ends directly, they introduced a modified telomerase RNA (TSQ1-hTR) (Diolaiti et al. 2013) into wild-type, MTH1 knockout, and PRDX1/MTH1 doubleknockout cells. TSQ1-hTR directs addition of 5'GTTGCC-3' repeats, which can be distinguished from wild-type $5^{\prime}$-TTAGGG- $3^{\prime}$ repeats in telomerase activity assays and Southern blot analysis. Despite comparable levels of mutant telomerase activity in all cell lines, MTH1 knockout and, to a greater extent, $P R D X 1 / M T H 1$ doubleknockout cells showed reduced incorporation of the mutant repeat after $21 \mathrm{PDs}$ in $20 \%$ (but not $5 \%$ ) $\mathrm{O}_{2}$ compared with wild-type cells, confirming the notion that telomerase action is inhibited at chromosome ends in the absence of MTH1 and PRDX1.

Finally, to assess the long-term impact of loss of MTH1 and PRDX1 on telomere integrity, wild-type and PRDX1/ MTH1 double-knockout cells were grown for 120 PDs in $20 \% \mathrm{O}_{2}$ and subjected to metaphase spread analysis. PRDX1/MTH1 double-knockout cells showed increased intrachromosomal telomere fusions, signal-free ends, and $\gamma-\mathrm{H} 2 \mathrm{AX}$ at telomeres compared with wild-type cells. These data, along with the observed increased levels of RPA32-S33 and the p53 target p21, indicate activation of the DNA damage response.

In conclusion, this study demonstrates that oxidative damage inhibits telomerase function in cancer cells. It therefore seems, at least in cancer cells, that the telomerase inhibitory effects of ROS-damaged telomeres win out. PRDX1/MTH1 double-knockout cells show continuous shortening of telomeres due ROS concentration-dependent inhibition of telomerase. PRDX1 and MTH1 prevent accumulation of oxidized guanine in the genome and retain telomeres in an extendable state (Fig. 1). Thus, these antioxidant systems are required to protect telomeres from oxidation and for cancer cell growth. Recent studies indicate that cancer cells may be more vulnerable than noncancer cells to damage by ROS (Sabharwal and Schumacker 2014). The work described here indicates telomerase as a source of that vulnerability. A significant prediction of this study is that combination therapy using ROS-inducing chemotherapeutic agents combined with inhibition of proteins that protect telomeres from ROS (such as PRDX1) could selectively target telomere maintenance in cancer cells.

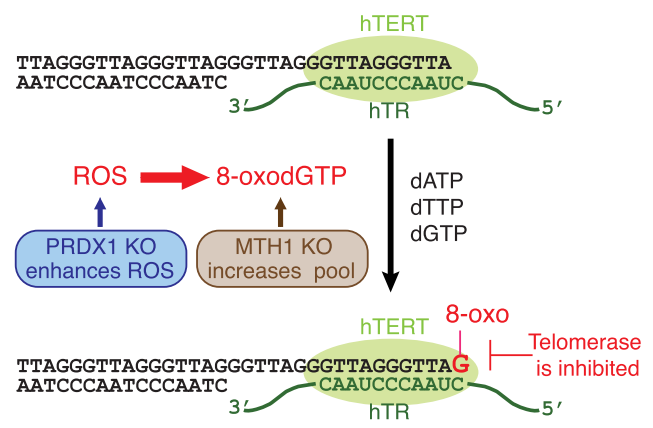

Figure 1. PRDX1 and MTH1 cooperate to prevent telomerase inhibition during oxidative stress. ROS oxidizes dGTP to 8-oxo dGTP. In the absence of MTH1, 8-oxo dGTP is not converted to 8 -oxo dGMP. The resulting increase in the 8-oxo dGTP pool leads to frequent incorporation by telomerase and chain termination. The loss of PRDX1, which increases ROS-promoted oxidation of dGTP to 8-oxo dGTP, further exacerbates the effects of MTH1 loss. Together, these two enzyme pathways ensure that telomeres exposed to oxidative stress are maintained in a telomerase-extendable state. 


\section{Acknowledgments}

S.S. is supported by National Cancer Institute grants R01CA200751 and R01CA116352.

\section{References}

Aeby E, Ahmed W, Redon S, Simanis V, Lingner J. 2016. Peroxiredoxin 1 protects telomeres from oxidative damage and preserves telomeric DNA for extension by telomerase. Cell Rep 17: 3107-3114.

Ahmed W, Lingner J. 2018. PRDX1 and MTH1 cooperate to prevent ROS-mediated inhibition of telomerase. Genes Dev (this issue). doi: 10.1101/gad.313460.118.

Diolaiti ME, Cimini BA, Kageyama R, Charles FA, Stohr BA. 2013. In situ visualization of telomere elongation patterns in human cells. Nucleic Acids Res 41: e176.

Fouquerel E, Lormand J, Bose A, Lee HT, Kim GS, Li J, Sobol RW, Freudenthal BD, Myong S, Opresko PL. 2016. Oxidative gua- nine base damage regulates human telomerase activity. Nat Struct Mol Biol 23: 1092-1100.

Lee HT, Bose A, Lee CY, Opresko PL, Myong S. 2017. Molecular mechanisms by which oxidative DNA damage promotes telomerase activity. Nucleic Acids Res 45: 11752-11765.

Loayza D, de Lange T. 2003. POT1 as a terminal transducer of TRF1 telomere length control. Nature 423: 1013-1018.

Oikawa S, Kawanishi S. 1999. Site-specific DNA damage at GGG sequence by oxidative stress may accelerate telomere shortening. FEBS Lett 453: 365-368.

Opresko PL, Fan J, Danzy S, Wilson DM III, Bohr VA. 2005. Oxidative damage in telomeric DNA disrupts recognition by TRF1 and TRF2. Nucleic Acids Res 33: 1230-1239.

Sabharwal SS, Schumacker PT. 2014. Mitochondrial ROS in cancer: initiators, amplifiers or an Achilles' heel? Nat Rev Cancer 14: 709-721.

van Steensel B, de Lange T. 1997. Control of telomere length by the human telomeric protein TRF1. Nature 385: 740-743.

von Zglinicki T. 2002. Oxidative stress shortens telomeres. Trends Biochem Sci 27: 339-344. 


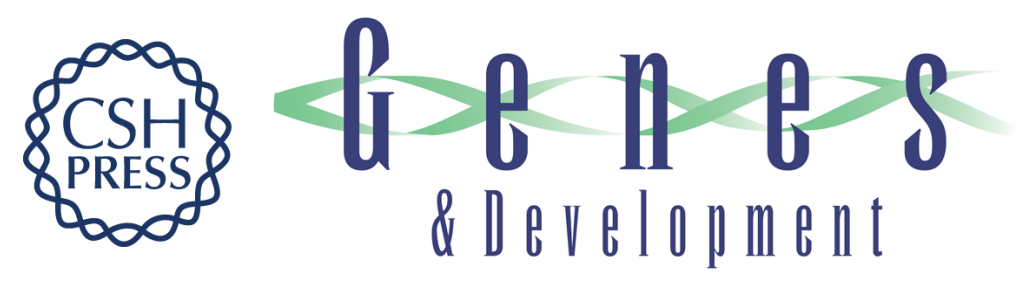

\section{Telomerase can't handle the stress}

Susan Smith

Genes Dev. 2018, 32:

Access the most recent version at doi:10.1101/gad.316042.118

\section{Related Content}

References

Creative

Commons

License

Email Alerting
PRDX1 and MTH1 cooperate to prevent ROS-mediated inhibition of telomerase Wareed Ahmed and Joachim Lingner Genes Dev. May , 2018 32: 658-669

This article cites 11 articles, 1 of which can be accessed free at: http://genesdev.cshlp.org/content/32/9-10/597.full.html\#ref-list-1

Articles cited in: http://genesdev.cshlp.org/content/32/9-10/597.full.html\#related-urls

This article is distributed exclusively by Cold Spring Harbor Laboratory Press for the first six months after the full-issue publication date (see

http://genesdev.cshlp.org/site/misc/terms.xhtml). After six months, it is available under a Creative Commons License (Attribution-NonCommercial 4.0 International), as described at http://creativecommons.org/licenses/by-nc/4.0/.

Receive free email alerts when new articles cite this article - sign up in the box at the top right corner of the article or click here.

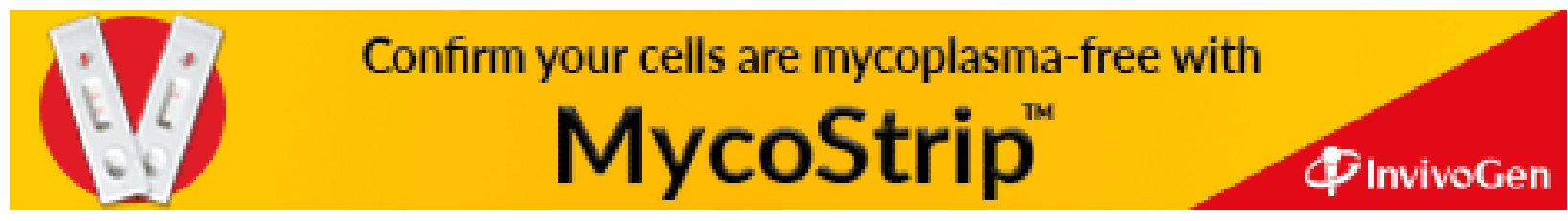

